Science Life

\title{
INTRODUCTION AND BREEDING OF RHODODENDRONS IN LATVIA
}

\author{
Rihards Kondratovičs and Uldis Kondratovičs ${ }^{\#}$
}

\author{
Experimental Rhododendron Breeding Nursery "Babīte", University of Latvia, "Rododendri", Spilve, \\ Babite regional community, LV-2101, LATVIA \\ \# Corresponding author, uldis.kondratovics@lu.lv
}

\begin{abstract}
Rhododendrons are relatively new beautiful ornamental plants in Latvia forming an essential part of public and private gardens, although they were introduced in Latvian territory already during the first half of $19^{\text {th }}$ century. Rhododendrons deserve their immense popularity due to the diversity of their habitat, size and type of blossoms and leaves and their flowering season. There are about 1000 rhododendron species in the wild up to now whereas breeders in various countries have created more than 30000 cultivars. Intensive rhododendrons introduction and acclimatization in Latvia started in 1957 when Rihards Kondratovičs, at the time director of the Botanical Garden, University of Latvia, started his research on the introduction and acclimatization of rhododendrons. Winterhardiness of about 400 wild species in Latvia was tested and 76 species were found to be suitable. Following the development of an extensive collection of wild rhododendron species and cultivars, the Rhododendron Breeding and Experimental Nursery "Babite", University of Latvia, was established at 1980 and the active breeding of new winterhardy cultivars was started. In 2017, the collection of outdoor rhododendrons of the University of Latvia consists of 76 species and 265 cultivars, including 109 cultivars bred in Latvia by Professor Rihards Kondratovičs.
\end{abstract}

Genus Rhododendron are outstanding ornamental plants of the family Ericaceae that have established themselves as a permanent element in landscape gardening and greening. Rhododendron plantings are an essential part of contemporary park design as well as public and private gardens. Rhododendrons deserve their immense popularity due to the diversity of their habitat, size and type of blossoms and leaves and their flowering season. In the wild some species that extend just a few centimeters above the ground can be found (Rh. lapponicum (L.) Wahlenb., Rh. nivale Hook. f.), many species are miniature shrubs, bushes, small trees and some even grow to a height of 30 meters (Rh. protistum var. giganteum (Forrest ex Tagg) D. F. Chamb.) (Cullen, 1980; Chamberlain, 1982; Berg and Heft, 1991). Similar diversity exists regarding colour, size and form of the flowers. We cannot imagine a single colour or shade that cannot be seen in rhododendron blossoms. The same is true for their leaves. They can be tiny, just about $1 \mathrm{~cm}$ long, while the average length of rhododendron leaves is $10-20 \mathrm{~cm}$. There are, however, some species with leaves of $20-70 \mathrm{~cm}(R h$. sinogrande Balfour f. \& W. W. Smith) long (Chamberlain, 1982). This extensive diversity offers landscape artists and gardeners ample opportunity to realize the most daring of ideas when designing landscapes, public green areas, or individual gardens.

The genus Rhododendron is extensive and diverse. Nowadays, rhododendrons grow mainly in temperate climates and in moist but well-drained sites. They are not common at low altitudes in hot equatorial forests, although they do occur (e.g., Rh. brookeanum. Low ex Lindl. of Borneo). They are abundant in the mountains of the equatorial high- island archipelago. They are rare or absent in deserts, grasslands, boreal forests or tundra. Except for Rh. lapponicum (and the Labrador teas if these are regarded as rhododendrons) which has adapted to the climatic extremes of arctic and alpine regions, rhododendrons flourish best in the habitats described above (Irving and Hebda 1993). Rhododendrons are not found on the continents of Africa and South America. Easy inter-crossbreeding is one of the typical characteristics of rhododendron. This trait presents breeders great opportunities to create new cultivars. Breeders all over the world take full advantage of these opportunities. There are about 1000 rhododendron species in the wild up to now (Chamberlain et al., 1996; Cox and Cox, 1997) whereas breeders in various countries have created more than 30000 cultivars (Anonymous, 2004). Thus, the number of cultivars created by humans exceeds the number of rhododendron species in the wild by a factor of about 30 .

The history of the rhododendron as a cultivated plant in Europe goes back almost three and one half centuries. In the $17^{\text {th }}$ century, the acrid haired rhododendron $(R h$. hirsutum L.), introduced from the Alps, was first cultivated in gardens (Berg and Heft, 1991). The origins of introduction of the genus Rhododendron in Latvia can be traced back to the 
1820s when the K. Vagners Company first offered their clients two rhododendron plant species. The J. Cigra and C. Sohs companies also played an important role in the introduction of rhododendron in Latvia. In the early $20^{\text {th }}$ century, rhododendrons started to appear in the parks and green areas of Rīga and Jūrmala. Rhododendron collections were established at the Bulduri School of Horticulture and the Botanical Garden, University of Latvia in the 1930s. In 1952, the Dubulti Fruit and Vegetable Farm started mass production of three rhododendron species for the parks in Riga and Jūrmala: Rh. japonicum Suring, Rh. luteum Sweet and Rh. catawbiense Michx. (Kondratovics U. et al., 2016).

Intensive rhododendron introduction and acclimatization in Latvia started in 1957 when Rihards Kondratovičs, director of the Botanical Garden, University of Latvia, at the time, started his research work on the introduction and acclimatization of rhododendron. The main research objective was to study winter hardiness and durability in Latvian climatic conditions for as many rhododendron species and cultivars as possible. During the next seven years, hardiness of about 400 wild species in Latvia was tested and 76 species were found to be suitable. Rhododendron seed for the developing collection came from Bremen (Germany), Gothenburg (Sweden), Bergen (Norway), Washington (USA), Vladivostok and Irkutsk (Russia) and other places, and they were collected during expeditions in the Far East, the Caucasus and the Carpathians. Cultivars were imported from the United Kingdom, Germany and the former Czechoslovakia. In addition to wild species, about 20 Western European outdoor cultivars have been introduced, but most of them were found to be unsuitable for cultivation in Latvia because of poor winter hardiness. However, they were useful later in breeding new local rhododendron cultivars (Kondratovics R. et al., 2016).

Along with the introduction and breeding of rhododendron, growing management methodology and propagation techniques were developed, anatomical structure, physiological and biochemical processes and their changes during their acclimatization were studied. At the same time, there was extensive public promotional work carried out by presenting rhododendron growing and propagation techniques and their practical application in plantings to horticulturists and others interested. For this purpose, the mass media, i.e. radio, TV and the press, was used, various seminars, courses, demonstrations and lectures were organised, and books and brochures were written (Kondratovics R. et al., 2016).

Following the development of an extensive collection of wild rhododendron species and cultivars, the breeding of new cultivars was started. To create new varieties, it is important to have enough high quality raw material which is used in generative hybridisation to acquire a large number of seedlings from which new cultivars are created using artificial selection. The first cross-breeding of outdoor rhododendron in Latvia was done in 1957. This work continued in the 1960s and was especially intense in the 1970s. Up to and including 2017, a total of 656 crosses in various combinations had been performed crossing species with species, species with cultivars, cultivars with species and cultivars with cultivars. Besides this, hybrid seedlings, acquired from seeds resulting from free pollination, were also used in the breeding process. Several tens of thousands of hybrid seedlings were acquired from all the 656 crosses. A large expanse of land was required to grow these seedlings to maturity. Since the Botanical Garden, University of Latvia, did not have this amount of land, it became necessary to establish a specialised nursery to successfully continue and further develop the breeding of rhododendron. In support of the University of Latvia request, the government allocated the university 12.1 hectares of pine forest land in Babite district for the purpose of developing a specialised rhododendron nursery (Kondratovics R. et al., 2016). The preliminary work was commenced immediately: the general plan for the nursery was devised by the head landscape architect of Riga K. Barons, a pool measuring 0.5 hectares was excavated for watering purposes, a road network was created, 3 $\mathrm{m}$ wide firebreaks, which divided the territory into $136 \mathrm{sec}-$ tions $(20 \times 30 \mathrm{~m})$, were cleared, a chain link fence was set up around the perimeter of the territory. After this preliminary work, the University of Latvia Rhododendron Breeding and Experimental Nursery "Babīte" was officially opened on 1 July 1980 by order of the rector of the University of Latvia (Kondratovics R. et al., 2016). Professor Rihards Kondratovics was entrusted to develop and to manage the nursery. Along with the establishment of the specialized rhododendron nursery, work with the genus Rhododendron mainly took place at the nursery while the Botanical Garden retained the rhododendron exhibition and some breeding materials.

Several goals were set forth for the newly established nursery which it has successfully attained over its 37 years of existence:

- to perform the introduction and breeding of rhododendron in order to create ornamental and cold-resistant cultivars of rhododendron suited for the agro climatic conditions of Latvia;

- to improve the existing methods and develop new effective methods of generative and vegetative propagation of species and varieties;

- to improve the crop management of rhododendron cultivation, to develop effective methods of disease and pest control;

- to study the anatomical, physiological and biochemical processes in rhododendrons during adaptation to new conditions thus increasing plant hardiness;

- to participate in the educational process by organizing work-study programmes and supporting Bachelors, Masters, and Doctoral thesis work;

- to make use of mass media to market rhododendron;

- to provide plants and literature about rhododendron to all interested parties. 
The nursery continues to meet the above goals. An extensive collection of outdoor rhododendron, which consists of 76 species and 265 cultivars, including 109 cultivars bred in Latvia, has been established.

Registration of new varieties was begun in 1999 upon the confirmation of the first nine outdoor rhododendron cultivars. Testing and rating of potential cultivars continues and every year new outdoor rhododendron cultivars are entered in the International Rhododendron Register and Checklist with Supplements of the Royal Horticulture Society in Great Britain (Anonymous, 2004). The creator of all the new cultivars is breeder Professor Rihards Kondratovičs.

The following 109 varieties of wild rhododendron have been developed, confirmed and registered up to and including 2017 (see Figs. 1-3):

- In 1999, 9 deciduous cultivars: 'Rubīns', 'Rīta Zvaigzne', 'Polārzvaigzne', 'Pasacina', 'Mazais Jefiñš', 'Babītes Līva', 'Babītes Indra', 'Babītes Inga', 'Babītes Astra'.
- In 2000, 4 deciduous cultivars: 'Babītes Anita', 'Babītes Laura', 'Uguns', 'Babītes Alīna' and 6 evergreen cultivars: 'Irina', 'Babītes Lavanda', 'Lita', 'Līgo', 'Sprīdītis', “Uldis'.

- In 2001, 5 deciduous cultivars: 'Ilze', 'Liene', 'Liesma', 'Skaidrīte', 'Teika' and 6 evergreen cultivars: 'Dace', 'Eduards Smiḷ̣̂is', 'Emīls', 'Babītes Ginta', 'Jānis', 'Kārlis'.

- In 2002, 5 deciduous cultivars: 'Saule', 'Madame Debene', 'Austra', 'Lorija', 'Ina'.

- In 2003, 3 deciduous cultivars: 'Francisa', 'Polonia', 'Riga' and 5 evergreen cultivars: 'Zinātṇu Akadēmija', 'Alma Mater', 'Babītes Baltais', 'Emeritus', 'Babītes Kristīne'.

- In 2005, 3 deciduous cultivars: 'Dzintra', 'Babītes Lidija', 'Arta' and 3 evergreen cultivars: 'Agris', 'Feja', 'LU Rolands'.

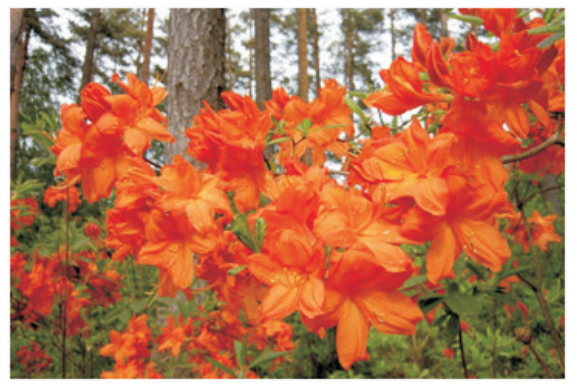

'Aura'

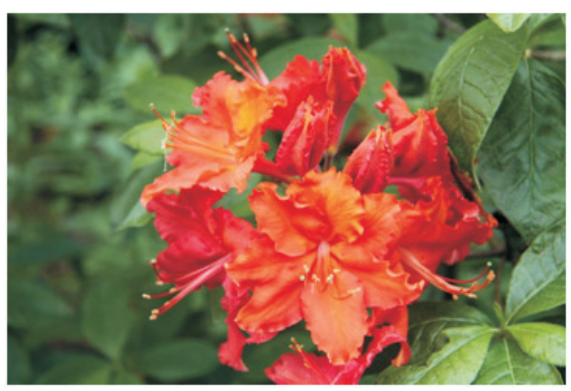

'Gunita'

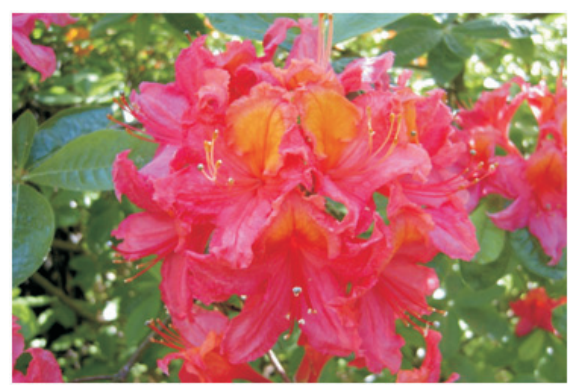

'Lelde'

Fig. 1. Some of deciduous rhododendron cultivars bred by Rihards Kondratovičs

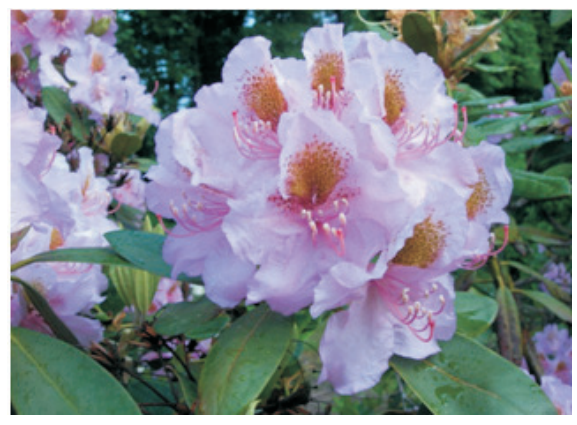

'Rektors'

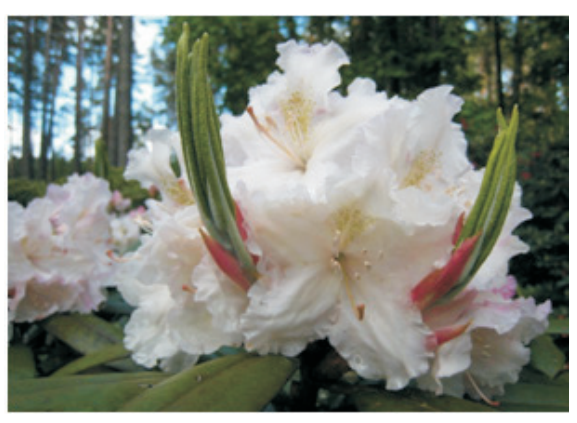

'Baltija'

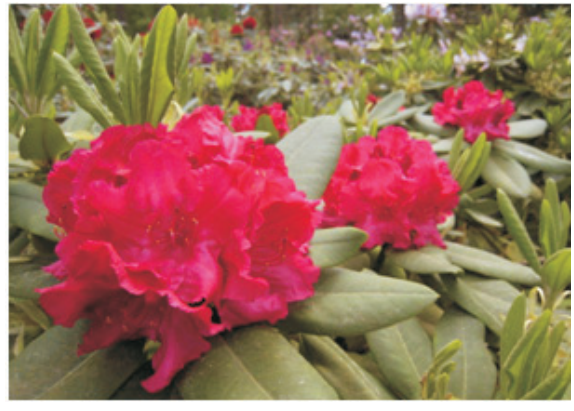

'Monta'

Fig. 2. Some of evergreen rhododendron cultivars bred by Rihards Kondratovičs.

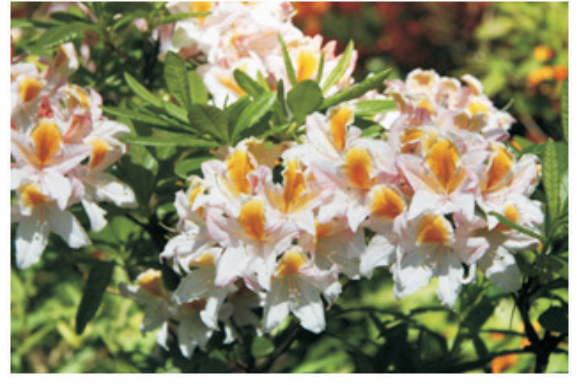

'Sarma'

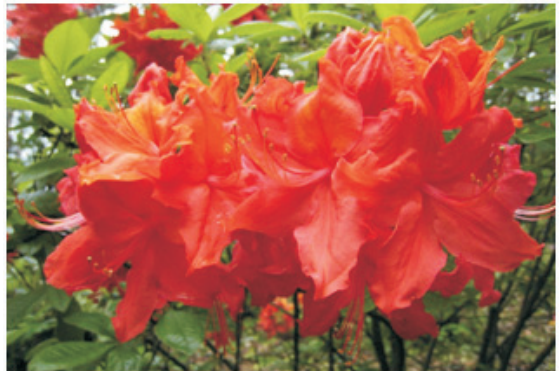

'Zvārtes Iezis'

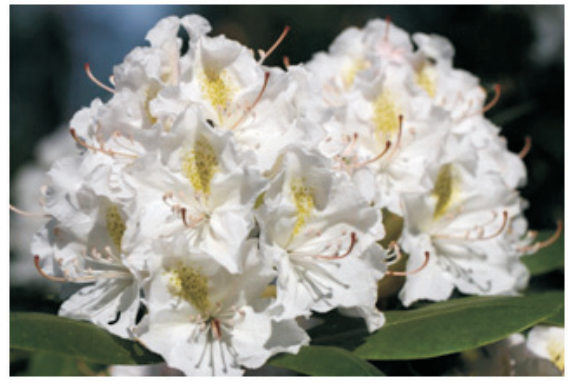

'Profesors Kondratovičs'

Fig. 3. Rhododendron cultivars registered in 2017. 


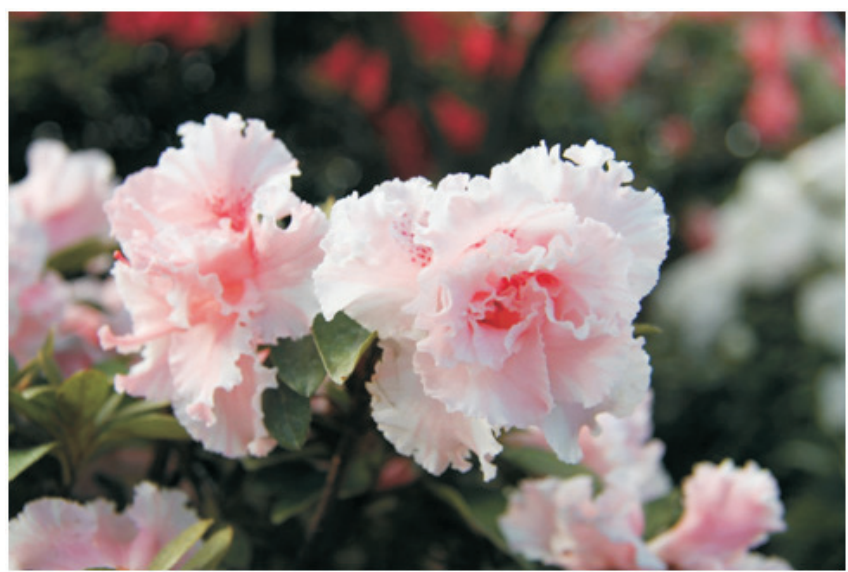

'Skaidrīte Matisone'

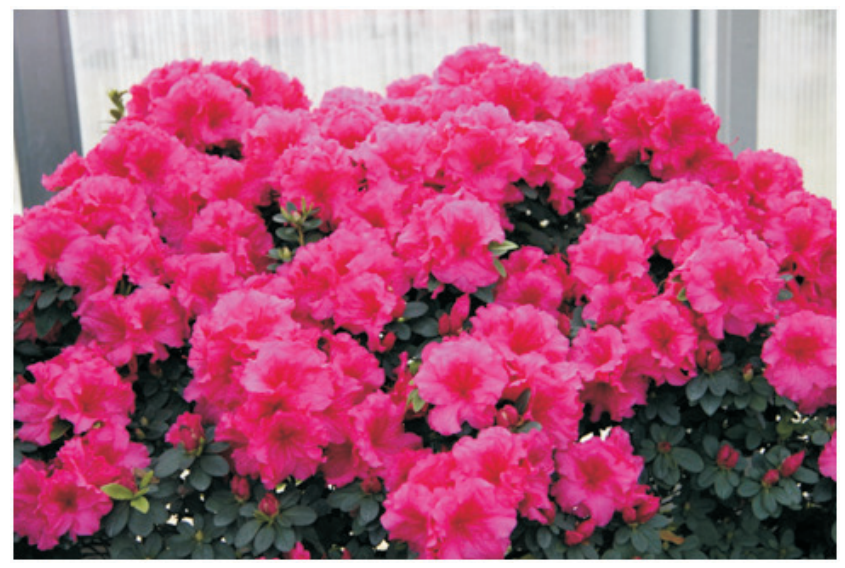

'Vēlziede'

Fig. 4. Greenhouse azalea cultivars registered in 2017.

- In 2007, 2 deciduous cultivars: 'Pērlīte' and 'Vija' and 3 evergreen cultivars: 'Kārlis Ulmanis', 'Robis', 'Rudìte'.

- In 2009, 3 evergreen cultivars: 'Atis', 'Aivars Lasis', 'Ilma'.

- In 2010, 2 deciduous cultivars: 'Dita Krenberga', 'Rasma' and 10 evergreen cultivars: 'Viesturs', 'Sofija', 'Egons', 'Toms', 'Andris', 'Miks', 'Imants', 'Biruta', 'Babītes Sarkanais', 'Tālavija'.

- In 2012, 4 deciduous cultivars: 'Ance', 'Baiba', 'Selga', 'TTT' and 5 evergreen cultivars: 'Babītes Kompaktais', 'Bulduri', 'Jānis Sproğis', 'Vilhelmīne Petkevičs', 'Vizma'.

- In 2013, 4 deciduous cultivars: 'Latvijas Itera', 'LU Solveiga', 'Ringla', 'Santa' and 4 evergreen cultivars: 'Doktors Babarikins', 'Dzidra', 'Indrikis', 'Valdis'.

- In 2014, 2 deciduous cultivars: 'Ausma', 'Ināra' and 5 evergreen cultivars: 'Babītes Antons', 'Babītes Elita', 'Elza Radzin,a', 'Kristaps Morbergs', 'Ogre's White Dream'.

- In 2015, 7 evergreen cultivars: ‘Aldonis Vērinšs', 'Babītes Aiga', 'Ilgonis', 'Mammadaba', 'Māra', 'Rektors', 'Teterevi Latvijai'.

- In 2016, 3 deciduous cultivars: 'Aura', 'Gunita', 'Lelde' and 3 evergreen cultivars: 'Baltija', 'Cīrava', 'Monta'.

- In 2017, 2 deciduous cultivars: 'Sarma', 'Zvārtes Iezis' and 1 evergreen cultivar - 'Profesors Kondratovičs', named after Rihards Kondratovičs already after his death (Fig. 3).

Breeding of outdoor rhododendron is ongoing and in the years to come Latvian gardeners, landscape artists and architects will continue to receive new ornamental and cold-resistant outdoor rhododendron cultivars.
Along with wild rhododendron species and cultivars introduction a collection of greenhouse azaleas (Rhododendon simsii) was created by breeding of new cultivars being an active aspect of the collection. As the result of many years of work, the University of Latvia Botanical Gardens collection has 126 varieties including 26 original locally bred cultivars (breeder R. Kondratovičs): 'Auseklītis', 'Columba', 'Duets', 'Dzige', 'Dzirkstelīte', 'Eldze', 'Ginta', 'Grācija', 'Ilva', 'Inta', 'Jolanta', 'Kārlis Sūniņš', 'Laima', 'Māsa Kerija', 'Meri', 'Momo', 'Ritenītis', 'Rožainā Zvaigznīte', 'Sarkangalvīte', 'Sārtais Dzintars', 'Saulriets', 'Sniegbaltīte', 'Sniegpārsla', 'Violetā Zvaigznìte', 'Vēlziede', and 'Skaidrìte Matisone' (two of them see on Fig. 3). The last of them 'Vēlziede' and 'Skaidrīte Matisone' (Fig. 4) were registered internationally already in 2017.

\section{Photographs by Gunita Riekstina}

\section{REFERENCES}

Anonymous (2004). International Rhododendron Register and Checklist. Royal Horticultural Society, London. 1544 pp.

Berg J., Heft L. (1991). Rhododendron und immergrüne Laubgehölze. 3. Aufl., Eugen Ulmer, Stuttgart. 272 S.

Chamberlain, D. F. (1982). A Revision of Rhododendron II. Subgenus Hymenanthes. Notes from the Royal Botanic Garden Edinburgh. 39 (2), 209-486.

Chamberlain, D., Hyam, R., Argent, G., Fairweather, G., Walter, K. S. (1996). The Genus Rhododendron, Its Classification and Synonymy. Royal Botanic Garden Edinburgh, Oxford, U. K. 181 pp.

Cox, P. A., Cox, K. N. E. (1997). Encyclopedia of Rhododendron Species. Glendoick Publishing. 416 pp.

Cullen, J. (1980). A Revision of Rhododendron I. Subgenus Rhododendron sections Rhododendron \& Pogonanthum. Notes from the Royal Botanic Garden Edinburgh. 39 (1), 1-207

Irving, E., Hebda, R. (1993). Concerning the origin and distribution of rhododendrons. J. Amer. Rhododendron Soc., 47 (3), 139-162

Kondratovics, U., Kondratovics, R., Riekstina, G. (2016). Die Geschichte der Rhododendron-Kultur in Lettland. In: Rhododendron und Immergrüne. Band 21. DRG, Bremen., S. 40-57 (in German).

Kondratovics, R., Kondratovics, U., Riekstina, G. (2016). Rhododendron Culture in Latvia. Rhododendrons International, Vol. 1, Part 2, pp. 77-87. Available at: https://www.rhododendron.org/ri/v1p2.pdf 
Rododendri Latvijā ir salīdzinoši jauna krāšņu dekoratīvo augu kultūra, tie veido sabiedrisko un privāto dārzu un citu apstādījumu būtisku dalı, kaut arī to introdukcijas pirmsākumi Latvijā meklējami tikai 19. gadsimta pirmajā pusē. Savu popularitāti rododendri iekarojuši, pateicoties to lielajai daudzveidībai, galvenokārt ziedu un lapu krāsai, kā arī ziedēšanas sezonai. Savvaḷā sastopamas aptuveni 1000 savvaḷas rododendru sugas, savukārt selekcionāri visā pasaulē līdz mūsdienām izveidojuši vairāk nekā 30000 škirnes. Intensīvs rododendru introdukcijas un selekcijas darbs Latvijā sākās 1957. gadā, kad toreizējais Latvijas Universitātes Botāniskā dārza direktors Rihards Kondratovičs uzsāka plānveidīgu rododendru goints izpēti. Tika pārbaudīta ap 400 savvaḷas rododendru sugu ziemcietība Latvijā, un par piemērotām audzēšanai Latvijas klimatā atzina 76 sugas. Turpinoties plašai rododendru savvaḷas sugu un škirņu kolekcijas veidošanai, 1980. gadā Latvijas Universitātē tika nodibināta Rododendru selekcijas un izmēǵinājumu audzētava "Babīte", un tādējādi aizsākās intensīva Latvijas klimatam piemērotu ziemciet̄̄gu rododendru šķiṇu selekcija. 2017. gadā Latvijas Universitātes brīvdabas rododendru škirņu kolekciju veido 76 savvalias sugas un 256 šķirnes, no kurām 109 ir izveidotas Latvijā (selekcionārs profesors Rihards Kondratovičs). 